\title{
International Sanitary Conferences from the Ottoman perspective (1851-1938)
}

\author{
Nermin Ersoy, Yuksel Gungor and Aslihan Akpinar
}

\section{Introduction}

The backdrop to the epidemics of the nineteenth century was the Industrial Revolution with the rapid increase of the urban population, unsanitary settlements in the vicinity of factories, long working hours and deterioration of living conditions for workers, malnutrition and the failure of nation-states to meet these challenges. ${ }^{1}$ The acceleration of transport due to the invention of steamships (1810) and the railway (1830) and the extension of international trade and pilgrimage via the Suez Channel (1869), as well as huge waves of migration from Europe to America led to the outbreak of the contagious diseases. ${ }^{2}$

Plague followed by other contagious diseases like cholera, typhus and tuberculosis were also exposed to Ottoman Land from the beginning of the nineteenth century to the beginning of the twentieth. In the first part of this era initiating the quarantine measures in Ottoman World was highly grueling because of protestations by the ulema (religious clergy) to whom diseases were the scourge of God on his unruly subjects. However with the pressure of the European powers, both quarantines and the other necessities enforced by them had been adminis-

1 Simon Szreter, "Industrialization and Health", British Medical Bulletin, 69 (2004), 75-86.; Marie-France Morel, "The Care of Children: The Influence of Medical Innovation and Medical Institutions on Infant Mortality 1750-1914”, in R. Schofield, D. Reher, and A. Bideau, eds., The Decline of Mortality in Europe, (Oxford Clarendon Press, 1991), pp. 196220.: Edwin Chadwick, "Report on the sanitary condition of the labouring population and on the means of its improvement", London May 1842, http://www.deltaomega.org/ ChadwickClassic.pdf, (accessed February 04, 2010); Bekir Metin and Sevim T. Aydın, Dünya Sağlık Örgütü ve Türkiye ile İlişkileri [Relations between the World Health Organization (WHO) and Turkey] (Ankara, 1997), http://195.142.135.65/who/yayinlar/DSO1.html (in Turkish), (accessed November 26, 2007).

2 Charles Issawi, An Economic History of the Middle East and North Africa (Columbia University Press, 1982); Obijiofor Aginam, "The Nineteenth Century Colonial Fingerprints on Public Health Diplomacy: A Postcolonial View", Law, Social Justice \& Global Development Journal 1 (2003). 
tered till the foundation of the Turkish Republic. In this study we aimed to analyze the international sanitary conferences and the affect of their consequences to the Ottoman State in the light of the historical sources and Ottoman archive documents.

The cholera epidemic could not be controlled despite the implementation of measures such as isolation and quarantine by affected countries that spanned the vast territory from Asia and the Arabian Peninsula to Anatolia, Europe and America. It was absolutely necessary for them to coordinate their efforts. Peter Frank (1745-1821) pioneered the idea of an international health organization, but he found no followers at the time. ${ }^{3}$

After his proposal, in 1831, Mehmet Ali Paşa, the Khedive of Egypt, set up a Sanitary Council managed by a commission of European diplomats (Commission Consulaire de Sante). This commission implemented and monitored corrective actions to prevent the spread of contagious diseases to Europe. In 1838, the Ottomans set out to deploy 77 public order and quarantine stations in Anatolia and along the borders. ${ }^{4}$ However, due to the dearth of local expertise and know-how in quarantine affairs, assistance was obtained from abroad. ${ }^{5}$ Germany, the United States, Austria, France, the Netherlands, England, Spain, Sweden, Iran, Norway, Russia and Greece responded to the call by the Minister of Foreign Affairs Mustafa Reşit Paşa on 10 January 1840 by each sending a delegate to the council, and Belgium and Italy followed suite in $1847 .{ }^{6}$

The 21-member Supreme Council of Health (Meclis-i Kebir-i Umur-u Sihhiye) assumed an international character with the joining of 13 foreign members, and separate quarantine councils were set up for Anatolia (Asia) and Rumelia (Europe). The Council in Istanbul acted as the seat of the organization. Dr. Bernard, Dr. Neuner, Dr. MacCarthy, Dr. Marchand and Dr. Francheschi were appointed during the term of Dr. Minas starting on January 1839; and Dr. Marchand, Dr. Andre Leval, Dr. Hermann, and Dr. Agopi known as the son of David, were appointed from February 1840 onwards when Lebib Efendi became

3 George Rosen, A History of Public Health, (The Johns Hopkins University Press, 1993), p. 267; Emine Melek Atabek, 1851'de Paris'te toplanan I. Uluslar arası Sağllk Konferansl ve Türkler [The First International Sanitary Conference that met in Paris in 1851 and the Turks] (İstanbul: İstanbul University Cerrahpaşa School of Medicine Publications, 1974), p. 14, (in Turkish).

4 Bedi N. Şehsuvaroğlu, "Türkiye Karantina Tarihine Giriş" [Introduction to the History of the Quarantine in Turkey, Introduction a l'histoire de la quarantaine en Turquie]," Journal of the İstanbul University School of Medicine 22(1) (1959), 326-27, (In Turkish and French).

5 Gülten Sarıyıldız, "Karantina," [Quarantine], in: Encyclopedia of Islam, Volume 24, (İstanbul: Foundation of Religious Affairs of Turkey, 2001), 464, (in Turkish).

6 Şehsuvaroğlu, "History of Quarantine in Turkey," 320. 
president. ${ }^{7}$ Known also as Meclis-i Umur-u Sihhiye, the members of the Council were Dr. Marchand, A. Pezzoni, J. Boskiyoviç, Dr. Agop, F. Lopyree, Dr. Andre Leval, Dr. Francheschi, Dr. Hermann and J. Vadina under the presidency of Baki Efendi. The inaugural meeting was held in İstanbul on 27 May 1840 and was presided over by Lebib Efendi. ${ }^{8}$ According to documents dated 15 March 1839, the penalties clauses of the Sanitary Quarantine Regulations were formulated in French following consultations with physicians and foreign delegates. ${ }^{9}$

The İstanbul Supreme Council of Sanitation was established in 1839 with the approval of Sultan Abdülmecit (1839-1861) to enforce quarantine regulations in the Mediterranean region. The Council consisted of 8 Ottoman members and delegates of 9 European states (Austria, Belgium, France, England, Greece, Prussia, Russia, Sardinia and Italy.) ${ }^{10}$ The local members consisted of the vice president, the interpreter, two Muslim officers and four physicians with degrees from European universities. Sixty-three sanitary agencies dispersed across the Ottoman domains reported to the Council. Each agency was administered jointly by a Muslim administrator and a European physician. ${ }^{11}$

During their meeting in Vienna in 1845, European and Ottoman envoys discussed quarantine techniques and pledged to improve them and to coordinate their efforts. ${ }^{12}$ The Vienna conference raised awareness on the critical role of international cooperation in the fight against epidemics and the series of International Sanitary Conferences were launched.

7 Ibid., 321.

8 Osman Şevki Uludağ, Son Kapitülasyonlardan Biri Karantina [Quarantine, One of the Last Concessions] (İstanbul: Devlet Publications, 1938), 445-451, (in Turkish).

9 Başbakanlık Osmanlı Arşivi (BOA.), [Prime Ministry Ottoman Archives], is a collection of historical sources related to Ottoman State, which contained more than 100 million archive documents mainly divided two groups as defter (registers) and evrak (individual documents) in addition to maps, photographs and albums. Prime Ministry Ottoman Archives, which mostly written in Ottoman Turkish, is open to international scholars, (see Ottoman archives, prepared by N. Aktaş and İ. Binark and edited by E. İhsanoglu (Istanbul, 1986); and T.C. Başbakanlık Devlet Arşivleri Genel Müdürlüğü http://www.devletarsivleri.gov.tr; BOA., Hatt-1 Hümayûn Tasnifi, (Number) 523/25535 and 25535A, (Date in Mohammedan calendar) 29/Zilhicce/1254, (Date in Gregorian calendar) $15 / \mathrm{March} / 1839$. This document is an imperial rescript about penalties clauses of the Sanitary Quarantine Regulations, (in Ottoman Turkish).

10 Atabek, First International Sanitary Conference and Turks, 49.

11 Metin and Aydin, WHO and Turkey.

12 BOA., İradeler, Hariciye (I. HR.), 31/1405, 21/Receb/1261, 26/July/1845. This document is an imperial order related to Ministry of Foreign Affairs about the Vienna meeting, (in Ottoman Turkish). 


\section{First International Sanitary Conference: Paris, 1851}

The first International Sanitary Conference to control epidemics began on 23 July 1851 at the Palace of the Foreign Ministry in Paris and 12 countries were represented, with the names of delegates being as follows: Ottoman State (Halphen, Dr. Bartoletti), France (C. E. David, Dr. Melier), England (Perrier, Dr. Sutherland), Spain (Segovia, Dr. Monlau), Toscany (Cecconi, Betti), Austria (Lavison, Dr. Menis), Sicily (Falcon, Dr. Carbonaro), the Vatican (Escalon, Dr. Cappello), Portugal (Grande Dr. Silveira), Sardinia (Magneto, Dr. Bo), Greece (Vitalis, Dr. Costi) and Russia (d'Ebeling, Dr. Rosenberger). Each country sent two delegates, one physician and one diplomat, and the French envoy C. E. David was elected as the chairman. ${ }^{13}$

The Ottoman State was represented by Halphen and Dr. Bartoletti, with Halphen handling political affairs and Dr. Bartoletti taking care of sanitary and health issues as mandated by the office of the French envoy. ${ }^{14}$

One of the key themes of this conference, the first international effort at controlling and preventing epidemics, ${ }^{15}$ was that cholera penetrated Europe through the Ottoman Empire which had become a breeding ground for this disease, and that the authorities had to play a more active role at prevention. ${ }^{16}$ Dr. Bartoletti challenged this view by stating that "cholera invaded Turkey in 1830 when there were no measures at prevention yet, and the quarantine system was put in place in 1838 to control land and sea access." He indicated that he had toured and made observations at the border with Asia, and was convinced that pilgrims from India carried the disease to Mecca through the Red Sea and infected Ottoman pilgrims. The Ottoman system of port clearance was also discussed and it was decided to reform rather than to abolish it. ${ }^{17}$

The main objective of the conference was to standardize isolation periods at the quarantines and lazarettos of the Mediterranean region and obtain the compliance of participating states. ${ }^{18}$ The targets were threefold, namely to protect

13 Atabek, First International Sanitary Conference and Turks, 32-33; Norman Howard Jones, "The Scientific Background of the International Sanitary Conferences, 18511938", (Geneva: World Health Organization, 1975), p. 10.

14 BOA., Hariciye Nezareti Mektubi Kalemi Belgeleri (HR. MKT.), 42/24, 28/Rabiulevvel/1268, 20/February/1852. This document is located at the documents of Cabinet of Ministry of Foreign Affairs, and it is about Dr. Bartoletti's attendance of Paris Sanitary Conference, (in Ottoman Turkish).

15 Michael McCarthy, "A brief history of the World Health Organization (Special Report)", The Lancet 360 (2002), 1111-1112.

16 Atabek, First International Sanitary Conference and Turks, 44.

17 Ibid., 43, 68.

18 Handan K1lınç, Isolating the subject: Cholera, Control and Sanitary Discourse in the Istanbul International Sanitary Conference of 1866 (Thesis in Master of Arts in History, Bogaziçi University, 2005), p. 31. 
public health, prevent damage to trade and international relations, and lay down quarantine regulations. ${ }^{19}$

During the second session on 5 August 1851, the French Minister of Foreign Affairs highlighted one of the objectives of the conference, stating that "the imbalance created in the international system and trade by having separate sanitary regulations has to be eliminated." The committee consisting of Dr. Bartoletti, Dr Carbonero (Sicily), Consul Dr. Grande (Portugal), Dr. Rosenberg (Russia), Dr. Sutherland (England) and Consul Vitalis (Greece) presented a report on the organization of health affairs in the Middle East and the creation of a cordon sanitaire on 11 November. ${ }^{20}$

Following 48 sessions and numerous committee meetings, an international health agreement with 137 articles was adopted. The representatives of 12 nations signed the first draft of on 19 December 1851 which was revised on 16 January 1852. The signatures of the representatives were not binding on their governments, and at the end of four months, only five countries had ratified the declaration. ${ }^{21}$ Later during the year the Sultan approved of the new quarantine regulation of Ottoman Empire. ${ }^{22}$ (Image 1).

Another archival document from 18 January 1853 indicates that the Ottoman state had signed a number of bilateral agreements on quarantine regulations, and that it had been decided with Austria, Sicily, Greece, Portugal, Russia and Sardinia and the Government of Toscana to meet in İstanbul to review the articles regarding quarantine and the appointment of physicians. ${ }^{23}$ Political issues would not be within the remit of this meeting, and states would comply with the consensual decisions, reserving the right to reject specific articles. ${ }^{24}$

19 Atabek, First International Sanitary Conference and Turks, 33, 34.

20 Ibid., 38-47.

21 Gregorio Delgado Garcia, Eduardo Estrella, and Judith Navarro, The Pan American Sanitary Code: Toward a Hemispheric Health Policy (Washington D. C., Pan American Health Organization (P.A.H.O, 1999): pp. 7-8.

22 BOA., İ. HR., 94/4596, 7/Rebiulahir/1269, 19/December/1852. This document is an imperial order related to Ministry of Foreign Affairs about The Quarantine Regulation was approved by imperial rescript, (in Ottoman Turkish).

23 BOA. HR. MKT., 54/100, 07/Rebiulahir/1269, 18/January/1853. This document is located in the documents of Cabinet of Ministry of Foreign Affairs, and it is about the agreement of quarantine regulations and reassignment of doctors, (in Ottoman Turkish).

24 Gülten Sarıyıldız, Hicaz Karantina Teşkilatı (1865-1914) [The Hicaz Quarantine Organization (1865-1914)], (Ankara, Turkish Historical Society Publications, 1996), pp. 1718, 61-68, (in Turkish). 
Image 1. Adoption of the quarantine regulation.

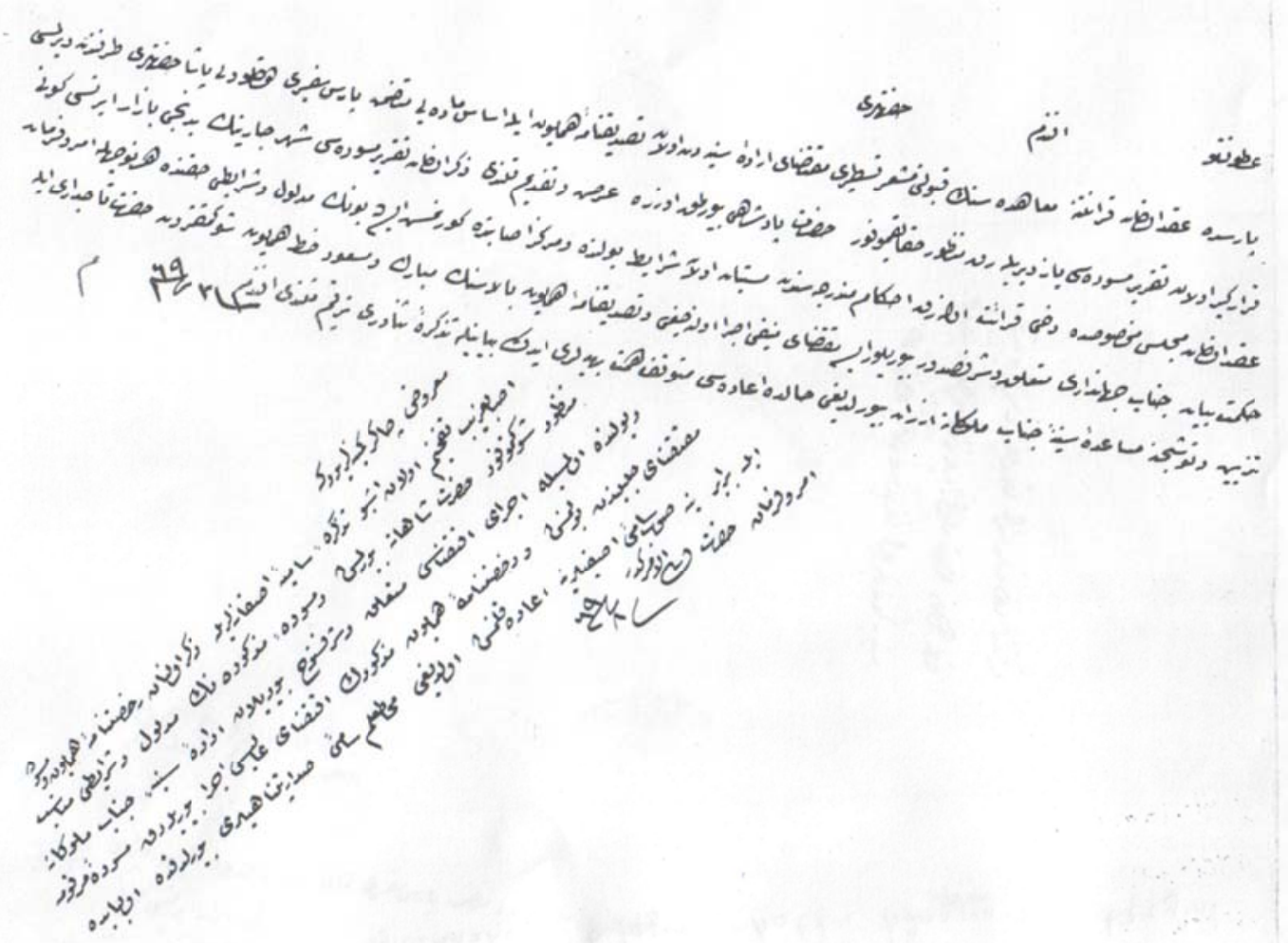

Source: Başbakanlık Osmanlı Arşivi, İradeler, Hariciye, Nr: 94/4596, Date: 19/December/1852.

\section{Second International Sanitary Conference: Paris, 1859}

Only diplomats and leading politicians participated in the second conference that began in Paris on 14 June $1859^{25}$ and extended over the next five months, with the objective of settling the political and economic disputes between the participating countries. ${ }^{26}$ It was proposed that a mandatory quarantine be introduced for incoming vessels from ports where there had been cases of cholera, and different types of quarantine in the Mediterranean region were explored. Standards of hygiene would be enforced in municipal areas, and the prohibition to bury the dead prior to notifying the quarantine administration would ensure proper record keeping. ${ }^{27}$

Documents from Ottoman archives from March 2 and 4, 1860 refer to the Health Regulation stipulating that deaths were to be registered, diseases to be reported to the quarantine administration and streets to be kept clean, and the

25 Peter Baldwin, Contagion and the State in Europe, 1830-1930 (Cambridge: Cambridge University Press, 1999), p. 199.

26 Garcia et al. "The Pan American Sanitary Code," 7-8.

27 NOVA Science Programming on Air and Online. "History of Quarantine," http://www.pbs.org/wgbh/nova/typhoid/quarantine.html (accessed November 26, 2007). 
dead were not to be buried without due notification. ${ }^{28}$ Nonetheless, a major outbreak of cholera was reported in India in 1865, which spread rapidly across Anatolia and Europe, and took a particularly heavy toll in the Hejaz. Prof. Proust reported that the necessary sanitary measures could not be enforced due to the conservatism of the population of Mecca, and argued that the epidemic had spread from the heap of the corpses of 30,000 pilgrims that had been stacked on sacrificed sheep. ${ }^{29}$

\section{Third International Sanitary Conference: İstanbul, 1866}

The Third International Sanitary Conference on cholera, known also as the Istanbul or Dersaadet Conference, was held in 1866 upon the initiative of France, which was responding to the rapid spread of the major cholera epidemic of 1865 from the Hejaz to Egypt and then to the Mediterranean region and Europe across land and maritime routes. ${ }^{30}$

The participants were the diplomats and physicians from a number of states: Ottoman state (Salih Efendi, Dr. Bartoletti), Austria (M. Vetsera, Dr. Sotto), Belgium (Noidans), Denmark (Dumreicher), Egypt (Salem Bey), England (William Stuart, Dr. E. D. Dickson, Dr. E. Goodeve), France (Lallemand, Dr. Fauvel), Greece (Kallergi, Dr. G. A. Maccas), Iran (Mirza Malcom Khan, Dr. Sawas Efendi), Italy (Alexandre Vernoni, Prof. Frederic Bosi, Dr. Salvatori), the Netherlands (Keun, Dr. Millingen), Portugal (Edouard Pinto de Soveral, Dr. B. A. Gomes), Prussia (Baron Testa, Dr. Muhlig), Russia (Dr. Pelikan, Dr. Lenz, Dr. Bykow), Spain (Don Antonio Maria Savogia, Dr. Pedro Felipe Monlau), Sweden and Norway (Oluf Stenersen, Dr. Hubsch) and the Vatican (Brunoni, Dr. Ignace Sparado). Eighteen states participated at the conference also known as the Galatasaray Conference with reference to the name of the school where it was held. ${ }^{31}$

28 BOA., Sadaret Mektubi Kalemi Umum Vilayet Yazışmalarına Ait Belgeler (A. MKT. UM.), 398/66, 9/Şaban/1276, 2/March/1860; BOA., A. MKT. UM., 398/77, 11/Şaban/1276, 4/March/1860. This document is located in the documents of the correspondence between the Cabinet of Prime Ministry and Provinces, and it is about registration of deaths and environmental sanitation, (in Ottoman Turkish).

29 Hasan Hüsrev Hatemi, "Dr. Kasım İzzettin'in "Kolera ve Mekke'de Hijyen” adlı Fransizca Eseri," [Dr. Kasım İzzettin's French Work Called Cholera and Hygiene in Mecca], Studies in Medical History 2 (1988), 79-84, (in Turkish).

30 Sheldon Watts, "From Rapid Change to Stasis: Official Responses to Cholera in British-Ruled India and Egypt: 1860 to c. 1921," Journal of World History 12(2) (2001), 344345.

31 K1lınç. "Isolating the subject," 33. 
Chief Physician Salih Efendi was appointed to chair the conference, and Dr. Bartoletti, who had participated at the conference in Paris, was to be deputy chair. Participation was broad due to the severity of the epidemic. The Minister of Foreign Affairs of the Ottoman state Ali Paşa (Image 2) delivered the opening speech of the conference that started on 13 February 1866 at the Galatasaray Academy ${ }^{32}$.

Image 2. Arrival of Ali Paşa at the opening ceremony at the Galatasaray Academy, Istanbul.

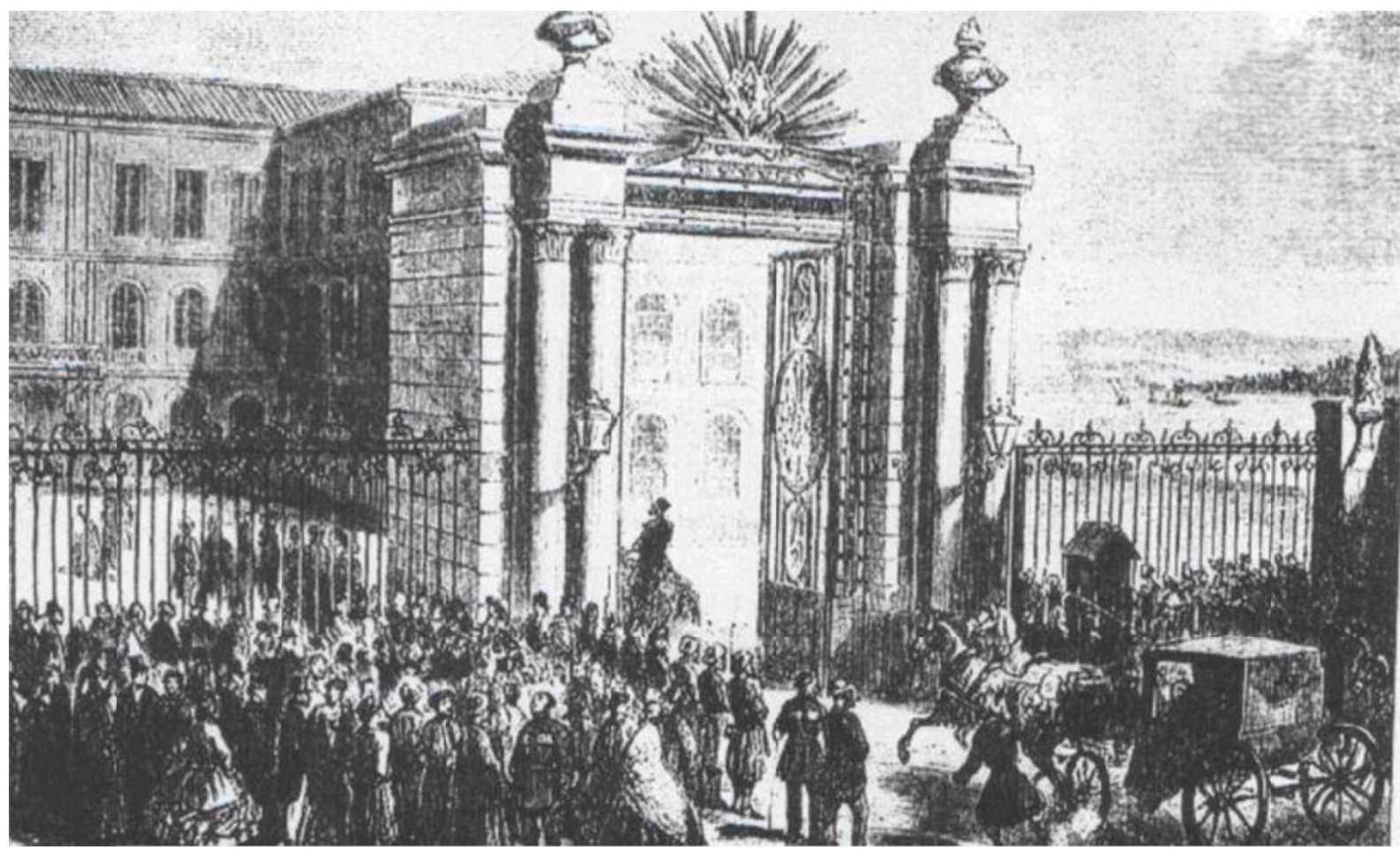

Source: Vahdettin Engin, "Galatasaray Mekteb-i Sultanisi” [School of Galatasaray], Journal of History and Civilization 35 (1997), 51.

The conference focused on measures against the cholera epidemic that broke out in the Hejaz. ${ }^{33}$ As the Hejaz belonged to the Ottoman Empire, French delegate Dr. Fauvel suggested in his keynote speech that "the Ottoman state promptly dispatch members of the Sanitary Commission to the Hejaz to report on the health condition of the pilgrims," and "seal off maritime traffic by sending a few warships to the region." 34

It was underlined that cholera had originated and spread from India, with Iranian delegates stressing the need to adapt quarantine measures to the incubation

32 Kilıç. "Isolating the subject," 33.

33 Orhan Koloğlu, "Osmanlı basınında 1865 kolera salgını, İstanbul Sağlık Konferansı ve Mirza Malkom Han" [The Ottoman press coverage of the 1865 cholera epidemic and Mirza Malkom Khan's argument in the Istanbul International Sanitary Conference] Studies in Ottoman Sciences 6:2 (2005), 139-150, (in Turkish).

34 Kilınç. "Isolating the subject," 34. 
period of the disease and to sanitize clothing, and the discussion focused on avoiding the spread of the epidemic to Europe rather than its elimination. The first proposal was to erect a gigantic quarantine station at Babülmendep, which was the gate to the Red Sea of Indian and other Eastern pilgrims. If this proved insufficient to contain cholera at the Hejaz, pilgrims would be directed to sanitation facilities at an appropriate site such as Eloca, failing which they would not be allowed to cross Egypt into Europe. It was further decided to set up quarantine stations on the border with Iran and to take specific measures against the spread of the disease over the Persian Gulf. ${ }^{35}$ The view that the Ottoman state was responsible for maritime transport and quarantine in the Straits was accepted by a large number of states. ${ }^{36}$

At the end of forty-four sessions, the cholera regulation had been revised according to the reports of the working groups and the principles of scientific quarantine, and the conference ended with the closing remarks of Ali Paşa on 26 September $1866 .^{37}$

Despite the prompt implementation of the decisions, cholera had arrived at the gate of Bucharest. Orders were issued to prohibit access to vessels that had not completed the stipulated quarantine term at İstanbul, Anadolu Kavağ 1 and to authorize municipal police to obstruct the access of vessels and passengers without proper documentation. ${ }^{38}$

\section{Fourth International Sanitary Conference: Vienna, 1874}

Within four years, the cholera outbreak in Russia in 1869 had spread to all of Central Europe, which had become more vulnerable after the opening of the Suez Channel. Russia proposed an International Sanitary Conference to forge an agreement with European states on a standard set of international quarantine rules. ${ }^{39}$ In the meantime, the Ottoman state proposed another conference to explore methods of preventing the spread of the plague that had broken out at

35 Uludağ, One of the Last Capitulations, 445-51.

36 Amir Arsalan Afkhami, "Defending the guarded domain: Epidemics and the emergence of an International Sanitary Policy in Iran," Comparative Studies of South Asia, Africa and the Middle East 19(1) (1999), 130.

37 Kilınç. "Isolating the subject," 69.

38 BOA., Dahiliye, Mektubi Kalemi (DH. MKT.), 1372/22, 15/Muharrem/1304, 14/October/1866. This document is located in documents of the Cabinet of Ministry of Interior Affairs and it is about quarantine regulations at Anadolu Kavağı, (in Ottoman Turkish).

39 Marcos Cueto, "Chapter 1: The Origins of International Public Health in the Americas," in The value of health: A history of the Pan American Health Organization (2006), p. 10, http://www.paho.org/English/DD/PUB/SP+600_Chapter 1.pdf (accessed November 26, 2007). 
the border with Iran. A considerable number of states, however, believed that the current health convention was adequate. ${ }^{40}$

The imperative of holding another sanitary conference became evident when the cholera outbreak during the Muslim festival of sacrifices in 1872 took a toll of 60,000 lives ${ }^{41}$ in just three months in Mecca and Egypt, from where it spread to Anatolia, Europe and the American continent. ${ }^{42}$ Austria proposed a conference where measures to prevent the spread of other epidemics like the Asian cholera would be discussed. The value of developing a unique set of standards had become apparent to an increasing number of states and the Fourth International Sanitary Conference convened in Vienna on 1 July 1874. One of the themes was municipal sanitation and rules of personal hygiene. At one point of the discussions, most of the delegates seemed to favour easing if not abolishing the quarantines. However, the argument of the Turkish mission (Ali Bey and Bartoletti Efendi) ${ }^{43}$ that the quarantine regulation based on the decisions of the İstanbul Sanitary Conference had to be strictly implemented was backed by the Greek delegation and carried the day. ${ }^{44}$ The Galatasaray Regulation thus remained in force. ${ }^{45}$

The view that the disease was air-borne prevailed during the conference ${ }^{46}$ where delegates from twenty-one countries including the Ottoman state partici-

40 Afkhami, "Defending the guarded domain," 130.

41 Istanbul Conference was the first of the conferences with respect to Hedjaz sanitary conditions and until the collapse of the Ottoman Empire Hedjaz was an important region which cared by European powers. Izzettin's book is an important source about Hedjaz sanitary conditions, in which he reported that 22 epidemics were emerged from 1831 to the beginning of 1900s. In this book, İzzettin was gave information and statistical data about cholera epidemics in the Muslim Holy Land, especially mortality rates and measures taken such as established commissions and incurred expenditure, e.g.1868 Hedjaz Sanitary Commission. Kasım İzzettin, Mekke-i Mükerreme'de Kolera ve Hıfzlsıhha [Cholera and Sanitation in Mekke-i Mükerreme] (İstanbul: İstanbul University Institute of Medical History Library no: o.1704, 1909), p. 32, (in Ottoman Turkish).

42 Similar to Izzettin's book in this study Dr. Proust gave some statistical data about deaths and information about how cholera was emerged and spread in Hedjaz region. He also gave numbers of the non Ottoman Muslim pilgrims. Dr. Proust, Sihhiyye Politikasinda Yeni Bir Cevelan Yani Sihhiyye Mes'ele-i Siyasiyyenin Hal ve Tesviyesi Hicaz Hacılarl, Trs. Ahmed Nermi, (İstanbul: İstanbul University Library, Nr: 4631), p. 64, (in Turkish).

43 BOA., İradeler, Dahiliye (İ. DH.), 692/48387, 24/Şevval/1291, 4/December/1874. This document is located in documents of imperial orders related to Ministry of Foreign Affairs, and it is about reports of Vienna Conference, (in Ottoman Turkish).

44 Uludağ, One of the Last Capitulations, 445-451.

45 Afkhami, "Defending the guarded domain," 129.

46 UCLA. School of Public Health, Department of Epidemiology. "Who first discovered Vibrio Cholera?," http://www.ph.ucla.edu/EPI/snow/firstdiscoveredcholera.html (accessed November 26, 2007). 
pated. ${ }^{47}$ Dr. John Snow's discovery that cholera spread to humans through contaminated water was received enthusiastically. ${ }^{48}$ A committee of physicians was set up to analyze the emerging data. Its task was to study the aetiology of cholera, the incubation period, prophylaxis and the epidemiology in vessels and ports, and assess the impact of the environmental conditions in the Eastern Mediterranean and the Black Sea on the spread of the disease. It was decided that the outcome of this work would constitute the basis for a new international health codex. ${ }^{49}$

Another remarkable aspect of the fourth conference was the unanimous adoption of the French proposal that "an international agency on epidemics be established with its headquarters in with its headquarters in Vienna."

\section{Fifth International Sanitary Conference: Washington, 1881}

The Fifth International Sanitary Conference took place in the USA in March 1881. Cholera threatened and yellow fever ravaged both sides of the Atlantic. ${ }^{51}$ The USA proposed to host the conference to promote the fight against cholera and yellow fever, and to develop an international sanitary system for the surveillance and monitoring for its ports and residential areas. ${ }^{52}$

The participants of the conference were ten delegates, most of whom were diplomats, from the west of the United States, and special envoys with expertise on medical subjects from four countries. ${ }^{53}$ Argentina, Brazil, Bolivia, Chile, Haiti, Mexico, Peru, the USA, Venezuela and Canada were represented. ${ }^{54}$ The conference was chaired by American delegate John Hay (1838-1905). ${ }^{55}$

The proposal of the delegate from South England to develop a standard system of reporting from the ports and their hinterland was discussed. ${ }^{56}$ The dele-

47 Howard-Jones, “The Scientific Background,” p. 39.

48 Ralph R. Frerichs, "Asiatic Cholera Pandemic of 1846-63,"

http://www.ph.ucla.edu/epi/snow/pandemic1846-63.html (accessed November 26, 2007).

49 Garcia et al. "The Pan American Sanitary Code," 7-8.

50 Ibid.

51 Pan American Health Organization (PAHO), "In the Beginning 1902-1920," in Pro Salute Novo Mundi A History of the Pan American Health Organization, (Washington, D.C.: P.A.H.O, 1992), p. 19, Full text version http://www.pitt.edu/Super1/lecture/lec0291/fulltext.htm (accessed November 26, 2007).

52 Hugh S. Cumming, "The International Sanitary Conference," American Journal of Public Health 16:10 (1926), 975.

53 P.A.H.O., "In the Beginning," 19.

54 Garcia et al. "The Pan American Sanitary Code," 7-8.

55 NNDB tracking the entire world, "John Hay,"

http://www.nndb.com/people/121/000059941/ (accessed November 26, 2007).

56 P.A.H.O., "In the Beginning," 19. 
gate from Austria-Hungary proposed that reports be submitted to two bureaus to be set up in Vienna and Havana. Sanitary reports from Europe, Asia and Africa would be submitted to the Vienna office, while reports from the Americas would be transmitted to Havana via telegraph. These proposals were discussed extensively. ${ }^{57}$

\section{Sixth International Sanitary Conference: Rome, 1885}

As epidemics spread rapidly in the Mediterranean in 1883 and claimed the lives of as many as 120,000 people only in Spain, ${ }^{58}$ preparations for a new conference came under way. The focus of the conference in Rome that convened upon the initiative of France and Germany ${ }^{59}$ was the fight against epidemics, although discussion revolved around drying up the major river beds at the origins of the disease and particularly in India, where the disease was believed to be endemic. ${ }^{60}$ The conference at which delegates from twenty-eight countries and the luminary Robert Koch participated, witnessed the start of a medical discussion on the aetiology of cholera. ${ }^{61}$ This was the first conference where the rights of India as an independent entity were asserted. Four English delegates, two of whom represented India, maintained that cholera had not spread from there. ${ }^{62}$ The Ottoman state was represented by Zeoros Bey. ${ }^{63}$

The conference began on 7 August 1885. Responding to the charge that England did not regulate tightly enough the quarantine on the route from India to the Suez Canal, it was decided to set up an independent committee to monitor the entry of vessels, mostly of English origin, to the Suez Canal. ${ }^{64}$

57 Garcia et al. "The Pan American Sanitary Code," 7-8.

58 "Cholera," The Encyclopedia Britannica, (London, 1926), p. 265.

59 Mariko Ogawa, "Uneasy Bedfellows: Science and Politics in the Refutation of Koch's Bacterial Theory of Cholera," Bulletin of History of Medicine 74 (2000), 697-98.

60 Krista Maglen, "Politics of Quarantine in the 19th Century," MSJAMA. 290:21 (2003), 2873.

61 "Who first discovered Cholera?"

62 Ogawa, "Uneasy Bedfellows," 698.

63 BOA., Yıldız Sadaret Hususi Maruzat Evrakı (Y. A. HUS.), 182/1, 1/Şaban/1302, 16/May/1885. This document is located in the documents related to Prime Ministry and their notifications of the Sultan, and it is about Zoiros Bey who would present Ottoman State in Roma Conference, (in Ottoman Turkish).

64 Maglen, "Politics of Quarantine," 2873. 


\section{Seventh International Sanitary Conference: Venice, 1892}

Although the opening of the Suez Canal in 1869 promoted trade, it also led to a cholera pandemic which was at this point claiming more lives in Europe than in India. Cholera spread like a wildfire due to the movement of vessels, most of which were of English origin, and North African pilgrims, and constituted a particularly strong threat France. ${ }^{65}$ It was decided to hold a seventh international sanitary conference in Venice on 30 January 1892 to promote international cooperation. ${ }^{66}$

The main theme of this conference was cholera, and quarantines and hygiene measures were extensively discussed.$^{67}$ French delegate Adrien Proust expressed his opinion on international measures. ${ }^{68}$ Failing to reach a consensus on some issues, European states set out to forge a convention that would be restricted to cholera. ${ }^{69}$ This convention on quarantines and hygiene that was drafted during the First International Sanitary Convention in 1892 was signed during the Seventh International Sanitary Conference in Venice. ${ }^{70}$

\section{Eighth International Sanitary Conference: Dresden, 1893}

The outbreak of cholera during the Hartwar festival in 1892 just a few days after the dispersion of the Hindu pilgrims followed by reported cases in Kabil in April, Herat and Tehran in May, Hamburg in August and then from New York, called for a new conference. ${ }^{71}$ The spread of cholera to most of the European continent and the fatalities at the ports of Paris, Hamburg, Baku and Russia led the Ottoman state to quarantine incoming trains from Europe. ${ }^{72}$

65 Ibid.

66 Elisabetta Minelli, "Chapter 1: Origin and Development of International Cooperation for Health: Steps Towards the Constitution of the World Health Organization," in World Health Organization: The mandate of a specialized agency of the United Nations, (Political Science Degree diss., State University of Milan, 2006). http://www.gfmer.ch/TMCAM/WHO_Minelli/P1-1.htm (accessed November 26, 2007).

67 Ibid.

68 Valeska Huber, "Contact Zone: Tourists, Slaves and Pilgrims in The Suez Canal Region Around 1900," (2006): 3, http://www.CU_Center_for_International_History (accessed November 26, 2007).

69 WHO. "Facilitation panel (FALP) Third meeting, Montreal, 12 to 16 February 2001, Information Paper, no: 2," http://www.icao.int/icao/en/atb/fal/panels/falp3/ip02e.pdf (accessed November 26, 2007).

70 Minelli, "Origin and Development".

71 "Cholera," The Encyclopedia Britannica: 265.

72 Nuran Yıldırım, "Tersane-i Amire Fabrikalarında Tebhir Makinesi/Etüv Üretimi ve kullanımı" [The Production and Use of Autoclaves at Ottoman Shipbuilding Plants] in 
The reported death toll in the Hejaz during this period was $40,000 .^{73}$ Claims were raised that the Ottoman state neglected health affairs in the region and the eighth International Sanitary Conference convened at Dresden focused on setting up a sanitary organization in that region. ${ }^{74}$

The theme of the conference that began on 29 March 1893 was hygiene and demographics. Methods of preventing the entry and spread of cholera to across borders were discussed. Participating states conceded to being surveyed by an international team of experts. ${ }^{75}$ There were lengthy discussions on whether cholera was borne through vessels, goods and passengers, and it was decided that measures had to take into account all instances. ${ }^{76}$

The Ottoman state, which had been represented at the Conference by Bonkovski Paşa, ${ }^{77}$ ratified the decisions, and proceeded to establish a sanitary organization with wide ranging powers to stem the Hejaz epidemic and to appoint sanitary officials to the ports following consultations with Dr. Izzeddin. ${ }^{78}$ The Ottoman state decided to award a salary to the Italian physician La Gope who had played a critical role in setting up the quarantines. ${ }^{79}$

\section{Ninth International Sanitary Conference: Paris, 1894}

Cholera broke out once again in the Hejaz during the pilgrimage season in $1893 .{ }^{80}$ The disease spread rapidly to Iran, Russia, Galicia and Europe and struck İstanbul in August. ${ }^{81}$ The Ninth Conference convened in Paris, which was hosting such a conference for the third time. A document from 13 January 1894 indi-

Reports at the Symposium of the Past and Present of the Golden Horn, May 22-23, 2003. ed. S. F. Göncüoğlu, İstanbul: Kadir Has University Publications, 2004), pp. 421-31, (in Turkish).

73 İzzettin, Cholera in Mekke-i Mükerreme, 32.

74 Sarıyldiz, The Hicaz Quarantine, pp. 17-18, 61-68.

75 Cueto, "International Public Health in the Americas," 10.

76 Uludağ, One of the Last Capitulations, 445-451.

77 BOA., Y. A. HUS., 271/18, 19/Şaban/1310, 8/March/1893. This document is located in documents related to Prime Ministry and their notifications of the Sultan about Bonkowski Pasha who would present Ottoman State in Dresden Conference, (in Ottoman Turkish).

78 Kasım İzzeddin, “Hicaz Sihhiye İdaresi-Hicaz'da Teşkilat ve Islahat-1 Sihhiye-1330 Y11 Hac Raporu" [Sanitary Organization in the Hejaz - Organisation and Sanitary Reform in the Hejaz, Pilgrimage Report from the Year 1330], (İstanbul, 1330--of Julien Calender-), pp. 52-3. This report dated 1914/1915, in National Library of Türkiye with the location number of 1973 SA 55. It is about sanitary measures in Hedjaz included members and tasks of Hedjaz Sanitary Council which established at 1910. (in Ottoman Turkish).

79 BOA., İradeler, Hususi (İ. HUS.), 9/1310/Ş-122, 15/Şaban/1310, 2/May/1893. This document is an imperial order about awarded salary of Dr. La Gope.

80 "Cholera," The Encyclopedia Britannica, 265.

81 Y1ldirım, "The Production and Use of Autoclaves," 421-431. 
cates that official measures against the spread of cholera through Bahr-1 Ahmer and the Persian Gulf were discussed, with Turhan Bey representing the Ottoman state. $^{82}$

The conference identified protective measures against the disease that was spreading over Eastern Europe, and decided to set up another quarantine station in the Gulf Region because of the belief that the disease spread to Europe over Iran, Russia and the Red Sea. It also determined to dispense medication in the Hejaz through a health delegation during Ramadan every year, to bolster the regional sanitary organization, and create a "sanitary police" made up of three officials. ${ }^{83}$

The proposal of the Italian delegates to improve the functioning of the İstanbul Supreme Sanitary Council by turning it into a hybrid body, or dispatch a separate delegation to Bahr-1 Ahmer and the Gulf for sanitary issues was rejected by Ottoman delegate Turhan Bey. ${ }^{84}$

A document from 3 March 1894 indicates that the decisions of the conference were being implemented. Turhan Bey was instructed to oversee the construction of quarantine at Şeyhsaid near the Strait of Babülmendeb that was designed specifically of pilgrims of Indian origin. ${ }^{85}$

The equipment with an autoclave of vessels carrying pilgrims from Ottoman ports to the Hejaz was a further reflection of a conference decision. ${ }^{86}$ Furthermore, the "discretionary quarantine" on pilgrimage boats that was based on an earlier sanitary regulation from 1 February 1880 was amended on 3 April 1895, and the quarantine period was extended from five to ten days. ${ }^{87}$ Following the outbreak of cholera in Mecca in 1895, measures regarding municipal cleaning, stricter compliance with hygiene rules in water distribution and the location of new constructions to out-of-town areas was enforced. Dr. İzzeddin reported that "a mission consisting of English delegate Dr. Clemow, German delegate Padel, Stekoulis, the delegate from Holland and myself was dispatched to the Hejaz

82 BOA., I.HUS., 30/1311/B-22, 6/Receb/1311, 13/January/1894. This document is an imperial order about payments and directives of Turhan Bey.

83 Şehsuvaroğlu, "History of Quarantine in Turkey," 338.

84 BOA., Y.A. HUS., 291/31, 20/Şaban/1311, 26/February/1894. This document is located in documents related to Prime Ministry and their notifications of the Sultan about instructions presented Turhan Bey concerning Paris Conference, (in Ottoman Turkish).

85 BOA., İ. HUS., 21/1311/Ş-085, 25/Şaban/1311, 3/March/1894. This document is an imperial order about construction to Turhan Bey related to quarantine at Şeyhsaid area.

86 Nuran Yıldırım, "Karantina" [Quarantina] in The Encyclopedia of İstanbul from Past to Present, (İstanbul: History Foundation Publications, 1994, Volume IV), p. 460, (in Turkish).

87 BOA., Meclis-i Umur-1 Sıhhiye Mazbataları, 27 Teşrin-i Sani 1900 tarihli oturum, nr: 19. This document is located in official reports of Supreme Council of Health, and it is dated the session on 3 April 1895. 
railway, and hospitals that would admit patients in case of an epidemic were assessed." ${ }^{88}$ According to a report from 1896, there were 65 quarantine stations in Anatolia, 17 on the border with Iran and 12 in the Red Sea area and the Hejaz, which employed a total of 511 individuals. $^{89}$

\section{Tenth International Sanitary Conference: Venice, 1897}

The plague, which was the new threat especially for Europe, constituted the main theme of the tenth International Sanitary Conference in Venice in 1897, whose mandate was to develop preventive measures. ${ }^{90}$ The Ottoman state was represented by a delegation consisting of Mr. Michel Cozzonis, who had succeeded Bartoletti as director general of quarantines, Dr. O. Vitolis and Dr. Mahmut Hakkı Bey. Dr. Cozzonis objected to the claim of the Italian delegate Fao that epidemics followed routes of pilgrimage, stating that "the disease appeared in Bombay five months prior to the last incidence of the plague, and the infection spread to Ottoman lands from the East." Cozzonis noted that as the Ottomans met their responsibility in restricting the access of pilgrims, the primary responsibility rested with England, which needed to take further measures regarding Indian pilgrims. His view that England could prevent the spread of epidemics in Ottoman domains and Europe if it was committed marked the conference. ${ }^{91}$

Not only did an international sanitary regulation emerge during the Tenth International Sanitary Conference but the International Sanitary Convention was also signed during that year. ${ }^{92}$ The theme of the Convention in Venice was the plague. $^{93}$

At the beginning of the twentieth century, discoveries about bacteriological diseases highlighted the critical role of scientific research in fighting epidemics and led to a more scientific approach to International Sanitary Conferences.

88 Hatemi, “Dr. Kasım İzzettin's French Work," 79-84.

89 Şehsuvaroğlu, "History of Quarantine in Turkey," 335-338.

90 Myron Echenberg, "Pestis Redux: The Initial Years of the Third Bubonic Plague Pandemic, 1894-1901," Journal of World History 13(2) (2002), 438.

91 Uludağ, One of the Last Capitulations, 459.

92 1897-EN. International Sanitary Convention for preventing the spread of the Plague, http://iea.uoregon.edu/TreatyTexts/1897-Sanitary.EN.txt (accessed November 26, 2007).

93 BOA., Y1ldız Sadaret Resmî Maruzat Evrakı (Y. A. RES.), 96/63, 27/Receb/1316, 11/December/1898. This document located in documents related to Prime Ministry and their request authority from the Sultan, and it is about agreed precautions against plague in Venice Conference, (in Ottoman Turkish). 


\section{Eleventh International Sanitary Conference: Paris, 1903}

At the time of the first conference of the twentieth century, the Ottomans had adopted a more scientific approach to the struggle against epidemic diseases. Twenty-one countries including the Ottoman state that was represented by Celal İsmail Paşa participated ${ }^{94}$ at the Paris conference where scientific measures against cholera and the plague were discussed. ${ }^{95}$ Proposals to lift the quarantine and to disinfect the hold of vessels were discussed, ${ }^{96}$ and scientific principles in the fight against cholera, the plague and yellow fever were laid down. ${ }^{97}$

The proposal of the French delegate for to establish an international office of public health, which may have been the most crucial aspect of the conference, was adopted through a majority vote. ${ }^{98}$ This permanent organization was to monitor epidemiological data and introduce quarantine standards. Besides, the Italian delegation proposed that the current Convention be amended to include issues of public health, safeguarding of commercial interests, and the revision and update of scientific data. ${ }^{99}$

Five years after the Eleventh International Sanitary Conference and Convention, representatives of twelve states assembled in Rome to set up a permanent office charged with enforcing the standards adopted at the conference. ${ }^{100}$ On December 9, 1907, they signed the Rome Treaty establishing the International Office of Public Health (OIHP) with a permanent secretariat in Paris. ${ }^{101}$

\section{Twelfth International Sanitary Conference: Paris, 1911-1912}

An Ottoman decree dated 8 December 1909 required all physicians to inform local government authorities or quarantine physicians of cholera or plague inci-

94 BOA., İradeler, Sihhiye, 4/1321/B-1, 14/Receb/1321, 6/October/1903. This document is an imperial order related to Ministry of Health and it is about whom to be sent to the Paris Conference, (in Ottoman Turkish).

95 Cueto, "International Public Health in the Americas," 10.

96 François Apéry, "Osmanlı İmparatorluğu'nda Veba ile Savaşan bir Eczacı: Pierre Apéry" [A Pharmacist Who Fought the Plague in the Ottoman Empire: Pierre Apéry] Studies in Ottoman Science 6:1 (2004), 15-33, (in Turkish).

$97 \mathrm{CMH}$ Working Paper Series, The historical perspective, p. 10, http://66.249.93.104/u/kou?q=cache:fRDki809cyIJ:www.whoindia.orgIEIP/CMH-Re (accessed November 26, 2007).

98 Metin and Aydin, WHO and Turkey.

99 Cumming, "The International Sanitary Conference," 976.

100 Ibid.

101 Minelli, "Origin and Development." 
dences. ${ }^{102}$ A further document from 20 February 1910 indicates that the Ottoman Empire had been invited by the director of the French School of Public Health M. Manyo to participate at the Congress of Schools of Public Health in Paris on August 2-10 August 1910, and had decided to send Adnan Bey and several other physicians. $^{103}$

Following this series of meetings, the Twelfth International Sanitary Conference was held in 1911 in Paris, which acted as host for the fifth time. The main theme of the conference was the method of bacteriological examination proposed by the French delegation and hygienic issues. Rejected at an earlier conference, the argument that mice played a role in the spread of the plague found support. The terms "healthy," "suspect" and "infected" were defined accurately to standardize the scientific terminology. ${ }^{104}$

The quarantine measures implemented by the Ministry of Health of the Ottoman State to prevent the spread of the cholera epidemic that broke out in Russia in 1910 and 1911, and methods for the sanitation of contaminated objects were improved. ${ }^{105}$ In addition an Ottoman document from 1911/1912 requested that funds be allocated for mobile quarantine stations in the Ottoman Empire. ${ }^{106}$ Participating states objected to tightening the quarantine despite clear indications that the Ottoman state sought to prevent the outbreak of a new epidemic through measures of which the major beneficiary would be West Europe, and the USA declined to sign the final declaration. The conference was adjourned and the focus shifted to the International Sanitary Convention, which was scheduled to be signed in Paris on 17 January 1912. ${ }^{107}$

102 BOA., Dahiliye Nezareti Muhaberat-1 Umumiye İdaresi Belgeleri (DH. MUİ.), 41/-1/ 35, 25/Zilkade/1327, 8/December/1909. This document located in documents of correspondence of the Cabinet of Ministry of Interior Affairs, and it is about necessity of the doctors' notification of all cholera and plague cases to authorities, (in Ottoman Turkish).

103 BOA., A. DH. MUI., 67/16, 9/Safer/1328, 20/February/1910. This document located in documents of correspondence of the Cabinet of Ministry of Interior Affairs, and it is about the doctors who would be sent to the Congress of Schools of Public Health in Paris, (in Ottoman Turkish).

104 Cumming, "The International Sanitary Conference," 976.

105 BOA., Tahrirat Kalemi Belgeleri (DH. EUM. THR.), 46/18, 10/Şaban/1328, 15/October/1910. This document located in documents of Editorial Office of Ministry of Interior Affairs, and it is about precautions of cholera contagion from Russia, (in Ottoman Turkish).

106 BOA, Umur-1 Mahalliye-i Vilayat Müdüriyeti Belgeleri (DH. UMVM.), 127/63, 11/Şaban/1332, 2/September/1914. This document located in documents of Budget Directory of Provinces of Ministry of Interior Affairs, and it is about funds for mobile quarantine stations, (in Ottoman Turkish).

107 Cumming, “The International Sanitary Conference," 977. 
Following the International Sanitary Convention of 1912, the conferences were interrupted until 1926 due to the outbreak of the First World War. ${ }^{108}$ International efforts to prevent and control disease were resumed after the war, triggered by epidemics of typhus and the flu. Claiming 15 million lives in 19181919, the flu revealed the imperative to set up an international organization spanning Europe, America, Asia and Africa. ${ }^{109}$ Furthermore, due to the severity of the malaria epidemics during the same period, an international conference was held in Warsaw in $1922,{ }^{110}$ and the International Malaria Commission was set up (1923). ${ }^{111}$ The public health measures proposed at the Warsaw Conference, the first occasion on which European states met after the war, were partially adopted during the Paris Sanitary Conference in $1926 .{ }^{112}$

\section{Thirteenth International Sanitary Conference: Paris, 1926}

The conference began on 3 May 1926 and culminated in a new Sanitary Convention that was signed by delegates of over sixty states. The French Minister of Health opened the conference that took place at the Palais d'Orsay, and M. Barrere was elected chairman. Committees were set up on two main issues, which were the organization chart of the International Office of Public Health and its permanent secretariat, and the standardization of the definition of an infected port or region and necessary measures. The responsibility of the newly founded Republic of Turkey to report on quarantine in the ports of the Dardanelles was defined and a joint protocol was signed. New regulations regarding maritime transport and quarantines were introduced to prevent the spread of the plague, cholera, yellow fever and other epidemics, and an exchange of information on the sanitary conditions in the Hejaz took place. ${ }^{113}$

During the International Sanitary Conventions in Paris in 1903, 1912 and 1926, the main themes were maritime transport and the condition of sanitary stations, and the responsibility of Arab states in the prevention of the spread of cholera from the holy sites through the pilgrims. At the International Sanitary Convention on 21 June 1926, states were represented at the level of plenipotentiaries and prime ministers, and measures to prevent the spread of typhus and

108 Ibid., 977-78.

109 Metin and Aydin, WHO and Turkey.

110 Marta Alexandra Balinska, "The National Institute of Hygiene and Public Health in Poland 1918-1939," Social History of Medicine 9(3) (1996), 431-432.

111 Metin and Aydin, WHO and Turkey.

112 Balinska, "Public Health in Poland," 432.

113 1926-Sanitary_EN. International Sanitary Convention, and Protocol of Signature. http://darkwing.uoregon.edu/ iea/TreatyTexts/1926-Sanitary.EN.txt (accessed November 26, 2007). 
smallpox were discussed. ${ }^{114}$ The convention was signed by Afghanistan, Albania, Argentina, Belgium, Brazil, Bulgaria, Czechoslovakia, Chile, China, Cuba, Denmark, the Dominican Republic, Equador, Egypt, England, Finland, France, Germany, Guatemala, Haiti, the Kingdom of the Hejaz, India, Greece, Habeshistan, Honduras, Hungary, Iran, Ireland, Italy, Japan, Liberia, Lithuania, Luxemburg, Mexico, Monaco, Morocco, the Netherlands, Norway, Paraguay, Peru, Poland, Portugal, Rumania, San Marino, Spain, Switzerland, Sudan, the USSR, Tunisia, Turkey, the USA, Uruguay and Venezuela. ${ }^{115}$

A new round of meetings to amend the resolutions of the Thirteenth International Sanitary Conference and the Convention began on 12 April 1933. Signed by the leading politicians of England, Ireland, the Commonwealth, India and France, the resolutions were based on the convention of 2 January 1902. The objective of the International Sanitary Convention of 1 August 1935 was to regulate air traffic and navigation. ${ }^{116}$

\section{Fourteenth and Final International Sanitary Conference: Paris, 1938}

Last but not least, the fourteenth International Sanitary Conference in Paris in 1938 attempted to review and update the decisions of the earlier conferences of 1926 and 1933, and to exchange knowledge on the most recent advances in bacteriology. $^{117}$

Quarantine regulations were revised and it was underlined that a sanitary observer had to be present during all travel. Diseases were classified, and the methods of epidemic control and laboratory tests were standardized. Egypt was assigned with setting up an International Sanitary Council in Alexandria to regulate and supervise the quarantines in the Mediterranean region, to meet standards of hygiene and regulate maritime transport. This organization was later turned into the Eastern Mediterranean Regional Office. ${ }^{118}$

On 31 October 1938, Germany, the Dominican Republic, Egypt, the USA, France, England, Ireland, India, Greece, Italy, Ethiopia, Japan, the Netherlands, Rumania and Sweden met to discuss the sanitary condition at the borders with

114 McCarthy, “A brief history," 1111-1112.

115 1926-Sanitary_EN.

116 France-Great Britain: Convention providing for the Reciprocal Enforcement of Judgments in Civil and Commercial Matters, with Protocol, The American Journal of International Law 31:1 (1937), 18-28

http://www.jstor.org/view/00029300/di982716/98p0227s/0 (accessed November 26, 2007).

117 McCarthy, "A brief history," 1111-1112.

118 Minelli, "Origin and Development." 
Egypt, its ports and quarantines. A set of procedures for access to Egyptian ports, the Red Sea and Suez Canal were drafted and submitted for signature. ${ }^{119}$

\section{Conclusion}

The search for international measures to prevent and control epidemics of cholera, the plague, yellow fever, malaria and typhus which ravaged the world throughout the 19th century, led to a series of International Sanitary Conferences under the leadership of European states. The conferences began in 1851 and ended in 1938. The International Sanitary Conferences, also called quarantine, health and sanitary conferences, took place in Paris in 1851 and 1859, İstanbul in 1866, Vienna in 1874, Washington D.C. in 1881, Rome in 1885, Venice in 1892, Dresden in 1893, Paris in 1894, Venice in 1897, and Paris in 1903, 1911, 1926 and 1938.

During these conferences, key concepts such as sanitation, disease and epidemics were defined and developed according to the most recent advances in microbiology, and methods to fight epidemics, quarantine techniques, prevention methods and rules of personal hygiene were debated. The critical importance of keeping towns and their drinking waters clean was recognized. Statistics on morbidity and mortality were kept, and the victims of epidemics were buried after disinfection. Although the basic objective of the conferences was to protect Europe from lethal diseases such as cholera and the plague and prevent damage to trade and transport from, they were also instrumental in reducing the frequency and severity of epidemics.

Complementing the International Sanitary Conferences of 1851-1938, a series of International Sanitary Conventions to establish international rules of quarantine regarding cholera, the plague and yellow fever, to enforce them, to develop travel and immigration policies and safeguard trade routes were ratified. The International Sanitary Conferences and Conventions laid the groundwork of the World Health Organization and current international legislation on the control of epidemics.

However the decisions made in International Sanitary Conferences were also means intervention in domestic affairs of Ottoman State and lots of decisions which made through 1851-1926 were extension of capitulations through the health care area. The Republic of Turkey which was born through Turkish War of Independence have been approached health care issues as a national issue and

119 Australian Treaty Series. 1939, No 4. Department of Foreign Affairs and Trade Canberra. Convention Amending the International Sanitary Convention of 21 June 1926, http://www.austlii.edu.au/au/other/dfat/treaties/1939/4.htm 
all capitulations included health were abolished in Lausanne agreement in $1923 .{ }^{120}$ In Turkey, after the Republic was constituted, the National Medical Congress convened in 1925. Especially first three congresses aimed to struggle against epidemics such as tuberculosis, malaria and syphilis. The health policies of the new Republic were shaped by the reports of these national congresses. ${ }^{121}$

Nermin Ersoy is Professor and Head of the Department of History of Medicine $\&$ Medical Ethics, School of Medicine, Kocaeli University.

Yuksel Gungor is Assistant Professor at Derbent School of Tourism, Kocaeli University.

Aslihan Akpinar is Research Assistant at the Department of History of Medicine $\&$ Medical Ethics, Health Sciences Institute, Kocaeli University.

120 Uludağ, One of the Last Capitulations, 459.

121 Murat Aksu, "Türkiye'de tüberküloz mücadelesinde II. Milli Türk Tıp Kongresi'nin yeri" [Importance of Second National Medical Congress in struggle of tuberculosis in Turkey] Proceeding book of IXth Congress of Turkish History of Medicine (Ankara: Nobel Publishing, 2006), pp. 323-2, (in Turkish). 


\section{References}

1897-EN. International Sanitary Convention for preventing the spread of the Plague, http://iea.uoregon.edu/TreatyTexts/1897-Sanitary.EN.txt (accessed November 26, 2007).

1926-Sanitary_EN. International Sanitary Convention, and Protocol of Signature. http://darkwing.uoregon.edu/ iea/TreatyTexts/1926-Sanitary.EN.txt (accessed November 26, 2007).

Afkhami, Amir Arsalan, "Defending the guarded domain: Epidemics and the emergence of an International Sanitary Policy in Iran," Comparative Studies of South Asia, Africa and the Middle East 19(1) (1999), 122-134.

Aginam, Obijiofor, "The Nineteenth Century Colonial Fingerprints on Public Health Diplomacy: A Postcolonial View", Law, Social Justice \& Global Development Journal 1 (2003).

Aksu, Murat, "Türkiye'de tüberküloz mücadelesinde II. Milli Türk Tip Kongresi'nin yeri" [Importance of Second National Medical Congress in struggle of tuberculosis in Turkey], pp.323-327, Proceeding book of IX ${ }^{\text {th }}$ Congress of Turkish History of Medicine, Ankara: Nobel Publishing, 2006.

Apéry, François, "Osmanlı İmparatorluğu'nda Veba ile Savaşan bir Eczacı: Pierre Apéry" [A Pharmacist Who Fought the Plague in the Ottoman Empire: Pierre Apéry] Studies in Ottoman Science 6(1) (2004), 15-33.

Atabek, Emine Melek, 1851'de Paris'te toplanan I. Uluslar arası Sağlık Konferansl ve Türkler [The First International Sanitary Conference that met in Paris in 1851 and the Turks] İstanbul: İstanbul University Cerrahpaşa School of Medicine Publications, 1974.

Australian Treaty Series. 1939, No 4. Department of Foreign Affairs and Trade Canberra. Convention Amending the International Sanitary Convention of

21 June 1926, http://www.austlii.edu.au/au/other/dfat/treaties/1939/4.htm

Baldwin, Peter, Contagion and the State in Europe, 1830-1930, Cambridge: Cambridge University Press, 1999.

Balinska, Marta Alexandra, "The National Institute of Hygiene and Public Health in Poland 1918-1939," Social History of Medicine 9(3) (1996), 427445.

Başbakanlık Osmanlı Arşivi (BOA.), Hatt-ı Hümayûn Tasnifi, (Number) 523/25535 and 25535A, (Date in Mohammedan calendar) 29/Zilhicce/1254, (Date in Gregorian calendar) 15/March/1839.

BOA., A. Dahiliye Nezareti Muhaberat-1 Umumiye İdaresi Belgeleri (DH. MUI.), 67/16, 9/Safer/1328, 20/February/1910.

BOA., A. Sadaret Mektubi Kalemi Umum Vilayet Yazışmalarına Ait Belgeler (MKT. UM.), 398/77, 11/Şaban/1276, 4/March/1860.

BOA., A. MKT. UM., 398/66, 9/Şaban/1276, 2/March/1860. 
BOA., Tahrirat Kalemi Belgeleri (DH. EUM. THR.), 46/18, 10/Şaban/1328, 15/October/1910.

BOA., Dahiliye, Mektubi Kalemi (DH. MKT.), 1372/22, 15/Muharrem/1304, 14/October/1866.

BOA., Dahiliye Nezareti Muhaberat-1 Umumiye İdaresi Belgeleri (DH. MUI.), 41/-1/35, 25/Zilkade/1327, 8/December/1909.

BOA., Umur-1 Mahalliye-i Vilayat Müdüriyeti Belgeleri (DH. UMVM.), 127/63, 11/Şaban/1332, 2/September/1914.

BOA., Hariciye Nezareti Mektubi Kalemi Belgeleri (HR. MKT.), 42/24, 28/Rabiulevvel/1268, 20/February/1852.

BOA., HR. MKT., 54/100, 07/Rebiulahir/1269, 18/January/1853.

BOA., İradeler, Dahiliye (İ. DH.), 692/48387, 24/Şevval/1291, 4/December/1874.

BOA., İradeler, Hariciye (İ. HR.), 31/1405, 21/Receb/1261, 26/July/1845.

BOA., İ. HR., 94/4596, 7/Rebiulahir/1269, 19/December/1852.

BOA., İradeler, Hususi (İ. HUS.), 21/1311/Ş-085, 25/Şaban/1311, 3/March/1894.

BOA., İ. HUS., 9/1310/Ş-122, 15/Şaban/1310, 2/May/1893.

BOA., İ.HUS., 30/1311/B-22, 6/Receb/1311, 13/January/1894.

BOA., İradeler, Sihhiye, 4/1321/B-1, 14/Receb/1321, 6/October/1903.

BOA., Meclis-i Umur-1 Sihhiye Mazbataları, 27 Teşrin-i Sani 1900 tarihli oturum, nr: 19.

BOA., Yıld1z Sadaret Hususi Maruzat Evrak1 (Y. A. HUS.), 182/1, 1/Şaban/1302, 16/May/1885.

BOA., Y. A. HUS., 271/18, 19/Şaban/1310, 8/March/1893.

BOA., Y. A. HUS., 291/31, 20/Şaban/1311, 26/February/1894.

BOA., Yıldız Sadaret Resmî Maruzat Evrakı (Y. A. RES.), 96/63, 27/Receb/1316, 11/December/1898.

Chadwick, Edwin, "Report on the sanitary condition of the labouring population and on the means of its improvement", London May 1842, http://www.deltaomega.org/ChadwickClassic.pdf, (accessed February 04, 2010).

Commission on Macroeconomics and Health, Working Paper Series, The historical perspective, p. 10, http://66.249.93.104/u/kou?q=cache:fRDki809cyIJ:www.whoindia.orgIEIP/ CMH-Re (accessed November 26, 2007).

Cueto, Marcos, "Chapter 1: The Origins of International Public Health in the Americas," in The value of health: A history of the Pan American Health Organization (2006), http://www.paho.org/English/DD/PUB/SP+600_Chapter_1.pdf (accessed November 26, 2007).

Cumming, Hugh S., "The International Sanitary Conference," American Journal of Public Health 16(10) (1926), 975-980. 
Dr. Proust, Sihhiyye Politikasinda Yeni Bir Cevelan Yani Sihhiyye Mes'ele-i Siyasiyyenin Hal ve Tesviyesi Hicaz Hactlarl, Trs. Ahmed Nermi, İstanbul: İstanbul University Library, Nr: 4631.

Echenberg, Myron, "Pestis Redux: The Initial Years of the Third Bubonic Plague Pandemic, 1894-1901," Journal of World History 13(2) (2002), 429449.

Elisabetta Minelli, "Chapter 1: Origin and Development of International Cooperation for Health: Steps Towards the Constitution of the World Health Organization," in World Health Organization: The mandate of a specialized agency of the United Nations, Political Science Degree diss., State University of Milan, 2006, http://www.gfmer.ch/TMCAM/WHO_Minelli/P1-1.htm (accessed November 26, 2007).

France-Great Britain: Convention providing for the Reciprocal Enforcement of Judgments in Civil and Commercial Matters, with Protocol, The American Journal of International Law 31(1) (1937), 18-28

http://www.jstor.org/view/00029300/di982716/98p0227s/0 (accessed November 26, 2007).

Garcia, Gregorio Delgado, Eduardo Estrella, and Judith Navarro, The Pan American Sanitary Code: Toward a Hemispheric Health Policy, Washington D. C., Pan American Health Organization, 1999.

Hatemi, Hasan Hüsrev, "Dr. Kasım İzzettin'in "Kolera ve Mekke'de Hijyen" adlı Fransızca Eseri," [Dr. Kasım İzzettin's French Work Called Cholera and Hygiene in Mecca], Studies in Medical History 2 (1988), 79-84.

Huber, Valeska, "Contact Zone: Tourists, Slaves and Pilgrims in The Suez Canal Region Around 1900," (2006): 3,

http://www.CU_Center_for_International_History (accessed November 26, 2007).

Issawi, Charles, An Economic History of the Middle East and North Africa, Columbia University Press, 1982.

İzzeddin, Kasım, "Hicaz Sıhhiye İdaresi-Hicaz'da Teşkilat ve Islahat-ı Sıhhiye1330 Y1lı Hac Raporu" [Sanitary Organization in the Hejaz - Organisation and Sanitary Reform in the Hejaz, Pilgrimage Report from the Year 1330], İstanbul, 1914/1915.

İzzettin, Kasım, Mekke-i Mükerreme'de Kolera ve Hifzısihha [Cholera and Sanitation in Mekke-i Mükerreme], İstanbul: İstanbul University Institute of Medical History Library no: o.1704, 1909.

Jones, Norman Howard, "The Scientific Background of the International Sanitary Conferences, 1851-1938", Geneva: World Health Organization, 1975. 
K1lıç, Handan, Isolating the subject: Cholera, Control and Sanitary Discourse in the Istanbul International Sanitary Conference of 1866, Thesis in Master of Arts in History, İstanbul, Bogaziçi University, 2005.

Koloğlu, Orhan, "Osmanlı basınında 1865 kolera salgını, İstanbul Sağlık Konferans1 ve Mirza Malkom Han" [The Ottoman press coverage of the 1865 cholera epidemic and Mirza Malkom Khan's argument in the Istanbul International Sanitary Conference] Studies in Ottoman Sciences 6(2) (2005), $139-150$.

Maglen, Krista, "Politics of Quarantine in the 19th Century," MSJAMA. 290:21 (2003), 2873.

McCarthy, Michael, "A brief history of the World Health Organization (Special Report)", The Lancet 360 (2002), 1111-1112.

Metin, Bekir and Sevim T. Aydın, Dünya Sağllk Örgütü ve Türkiye ile İlişkileri [Relations between the World Health Organization (WHO) and Turkey] (Ankara, 1997), http://195.142.135.65/who/yayinlar/DSO1.html (in Turkish), (accessed November 26, 2007).

Morel, Marie-France, "The Care of Children: The Influence of Medical Innovation and Medical Institutions on Infant Mortality 1750-1914”, pp. 196-220 in R. Schofield, D. Reher, and A. Bideau, eds., The Decline of Mortality in Europe, Oxford Clarendon Press, 1991.

NNDB tracking the entire world, "John Hay," http://www.nndb.com/ people/121/000059941/ (accessed November 26, 2007).

NOVA Science Programming on Air and Online. "History of Quarantine," http://www.pbs.org/wgbh/nova/typhoid/quarantine.html (accessed November 26, 2007).

Ogawa, Mariko, "Uneasy Bedfellows: Science and Politics in the Refutation of Koch's Bacterial Theory of Cholera," Bulletin of History of Medicine 74(4) (2000), 671-707.

Pan American Health Organization (PAHO), "In the Beginning 1902-1920," in Pro Salute Novo Mundi A History of the Pan American Health Organization, Washington, D.C.: P.A.H.O, 1992, Full text version

http://www.pitt.edu/Super1/lecture/lec0291/fulltext.htm (accessed November 26, 2007).

Ralph R. Frerichs, "Asiatic Cholera Pandemic of 1846-1863,"

http://www.ph.ucla.edu/epi/snow/pandemic1846-63.html (accessed November 26, 2007).

Rosen, George, A History of Public Health, The Johns Hopkins University Press, 1993.

Sarıyıldız, Gülten, "Karantina," [Quarantine], in: Encyclopedia of Islam, Volume 24, İstanbul: Foundation of Religious Affairs of Turkey, 2001. 
Sarıyıldız, Gülten, Hicaz Karantina Teşkilatı (1865-1914) [The Hicaz Quarantine Organization (1865-1914)], Ankara, Turkish Historical Society Publications, 1996.

Şehsuvaroğlu, Bedi N., "Türkiye Karantina Tarihine Giriş" [Introduction to the History of the Quarantine in Turkey, Introduction a l'histoire de la quarantaine en Turquie]," Journal of the Istanbul University School of Medicine 22(1) (1959).

Szreter, Simon, "Industrialization and Health", British Medical Bulletin, 69 (2004), 75-86.

The Encyclopedia Britannica, "Cholera," London, 1926, p. 265.

University of California, Los Angeles. School of Public Health, Department of Epidemiology. "Who first discovered Vibrio Cholera?,"

http://www.ph.ucla.edu/EPI/snow/firstdiscoveredcholera.html (accessed November 26, 2007).

Uludağ, Osman Şevki, Son Kapitülasyonlardan Biri Karantina [Quarantine, One of the Last Concessions], İstanbul: Devlet Publications, 1938.

Watts, Sheldon, "From Rapid Change to Stasis: Official Responses to Cholera in British-Ruled India and Egypt: 1860 to c. 1921," Journal of World History 12(2) (2001), 321-374.

World Health Organization, "Facilitation Panel Third Meeting, Montreal, 12 to 16 February 2001, Information Paper, no: 2," http://www.icao.int/icao/en/ atb/fal/panels/falp3/ip02e.pdf (accessed November 26, 2007).

Y1ldırım, Nuran, "Karantina" [Quarantina] in The Encyclopedia of Istanbul from Past to Present, İstanbul: History Foundation Publications, 1994, Volume IV.

Yıldırım, Nuran, "Tersane-i Amire Fabrikalarında Tebhir Makinesi/Etüv Üretimi ve kullanımı" [The Production and Use of Autoclaves at Ottoman Shipbuilding Plants] pp. 421-31, in Reports at the Symposium of the Past and Present of the Golden Horn, May 22-23, 2003. ed. S. F. Göncüoğlu, İstanbul: Kadir Has University Publications, 2004. 